\title{
TEACHERS' COMPREHENSIONS, PERCEPTIONS, AND ATTITUDES TOWARDS INCLUSIVE EDUCATION
}

\author{
Ruwandi \\ Postgraduate Student of Yogyakarta State University (YSU) \\ ruwandi.ruwandi8@gmail.com
}

\begin{abstract}
This study aims at finding out 1) the comprebensions of Islamic Elementary School Teachers (MI) in Salatiga to inclusive education; 2) their perceptions; and 3) their attitudes to the inclusive education. This is a survey research. The primary data collection method used in this research was questionnaires, besides structural interviews. Based upon the calculation of the questionnaires, the writer found out that 1) the teachers' comprebension to inclusive education is still low (88.1\%) and only $4.7 \%$ feels having a little knowledge about it. In addition, $50.02 \%$ have negative perceptions, and are only $21.46 \%$ who have positive perceptions to it. Even though, $43.89 \%$ have positive attitudes and 37.81 have negative attitudes to the inclusive education.
\end{abstract}

Keywords: Comprehensions, Perceptions, Attitudes, Inclusion

\begin{abstract}
Abstrak
Penelitian ini bertujuan untuk menganalisis 1) pemabaman guru-guru Madrasah Ibtidaiyah di Kota Salatiga terhadap pendidikan inklusi; 2) persepsi mereka; dan 3) sikap mereka terhadap pendidikan inklusi. Penelitian ini menggunakan metode survey. Metode pengumpul data yang digunakan adalab kuesioner disamping wawancara terstruktur. Hasil kalkulasi and analisis kuesioner menunjukkan babwa sebagaian besar guru Madrasah Ibtidaiyah (88,1\%) belum memahami makna pendidikan inklusi, and banya 4,7\% saja yang memiliki sedikit pemahaman tentang inklusi. Kedua, sebagian guru-guru MI juga memiliki persepsi negative (50,02\%) terhadap pendidian iklusi dan sekitar 21,46\% memiliki persepsi positif. Ketiga, meskipun mereka belum sepenubnya memahami pendidikan inklusi and memiliki persepsi negative terhadapnya, namun mereka memiliki sikap positif (43,89\%), dan sisanya $(37,81 \%)$ bersikap negative terhadap pendidikan inklusi.
\end{abstract}


Kata kunci: Pemahaman, Persepsi, Sikap, Inklusi

\section{Introduction}

Inclusion is the worldwide agenda so as to inclusive education. The issue of inclusive education has become important part of the discussions on the progress of education systems in the worldwide level. Inclusive education practices have also been implemented in several schools in diversified education systems (Ballard, 2005:1). In the worldwide, inclusion becomes a major focus of the policies of many governments (Armstrong at.al, 2010:3).

Indonesia, one of the worldwide countries in the world has conceptualized the ideas of inclusive education. The ideas have been formulated in Indonesian Republic Regulations Number 20 Year 2003 about National Education System in Chapter IV, article 5, verses 1,2,3,4, and 5. Based upon the regulations, the concept of inclusive education is beyond special education because it accommodates several differences possessed students not only because of mental but also non-mental retardations. For the reasons, inclusive education is a very big business which needs to be conceptually and operationally understood.

Since the ideas of inclusive education are still universal, academic experts and practitioners have not yet agreed concerning the conceptualization of it. In addition, the interpretations of the inclusive education are also various. Furthermore, if it refers to the ideas proposed in the regulations. There has not been a clear cut of inclusive education, so who should be included and who should be excluded from inclusion, when there is no separation between students with special needs and regular students such as in United States. When inclusive students are separated from regular students as in The Netherlands, what special education looks like; how many special educations should be built around the country, cities, towns, districts, and villages; to what extent is the capability of parents to send their children when there is only one special education in a town or a city; and to what extent is the capability of government to provide the well-educated and skilled inclusion teachers, inclusive curricula, approaches, methods, teaching aids, school buildings, 
infrastructures, and the like.

Inclusive education as said in the regulations is a big umbrella. In inclusive education there can be many special educations. But the problems of special educations themselves vary from one and another. Some students could not be integrated in regular schools because their difficulties could not be solved in the schools; let us say those who are permanently deaf and blind since there were children. Therefore, they might be separated from regular students. On the other hand, there are many students who are able to be integrated in regular schools because their difficulties could be coped with by the schools; thus there is no reason for segregation, as students with special intelligences who are able to join in accelerated classes in regular schools. The case in Yogyakarta City is one of several examples (Sindo, April $7^{\text {th }}$, 2012). In the city, inclusive classroom for students with special intelligences was developed to follow up some establishments of some inclusive school practices such as Muhammadiyah Elementary School in Sapen and State Elementary School in Giwangan; State Junior High School 2 and 5 and Muhammadiyah 2 Junior High School; and State Senior High School 1 and 3, and Muhammadiyah 1 Senior High School. How are about students with high-special needs as categorized by Jere Brophy (1996) and by Brenda Freeman (1994) who are characterized as (1) passive, (2) aggressive, (3) attention problems, (4) perfectionist, and (5) socially inept (Marzano, 2003: 55)? Should they be left behind even though they have the same rights as the students with special intelligences?

Since there are still multi interpretations and practices concerning the conceptualizations and practices of inclusive education, the relating educational agents should take a seat together to conceptualize operationally what inclusive education means. In addition, this must be followed by socialization and preparation of the infrastructures needed in the inclusion.

In the writer's points of view, one of the fundamental steps for inclusion practice namely socialization should be taken into account. The fact, however, it has not yet been conducted comprehensively. The socialization does not only discuss the concep- 
tualization, but also the specification and the implementation ways of inclusive education. In the processes all the participants should also talk about all related sources needed for the conduct of the inclusive education. Among others are teachers' knowledge and skills for inclusion, curricula, teaching media, teaching approaches, books, and the like.

In the pre-research interviews conducted in October 2012, the writer found out polarizing facts particularly concerning teachers' comprehension towards inclusive education. Most of the interviewees in State Islamic Elementary Schools (MI) Gamol Salatiga argued that they were still confused about the terms and of course the implementation of inclusive education. They were confused because whether or not inclusive education includes those who are disabling mentally and physically. Were they any limitations? Mentally and physically, are all disable students should be fused in regular classes. When there are limitations, what are the limitations and how to implement such a concept? What should be done by teachers when there are passive students, extra-naughty students, aggressive students, and etcetera?

Besides confusion in the conceptualization, most of teachers also could not access information about inclusive education from the responsible education agents. So far there is no socialization, seminar or workshop which is conducted by the agents such as the Ministry of Religious Affairs or for the extent the Ministry of Education Affairs as well as University Institutions. The comprehensions of inclusive education are much needed because in their comprehensions they always face to face with inclusion. By comprehending the concept of inclusive education, they expect that they are able to cope with problems of inclusion.

Borrowing Rose's ideas (2010: 1-2), it is understandable that understanding demands efforts. Even at the age of increased mass communication technology when it is relatively simple to share ideas and perspectives but it is not always easy to interpret the meaning of the messages we receive. Accordingly, direct access to the inclusion through socialization, seminar, and workshop is very important. 
Teachers have insufficient knowledge towards inclusive education because of several reasons:

1. Inclusive education is considered as a new education phenomenon so most of the teachers do not take into account.

2. Inclusive education is necessary to understand but they do not have sufficient access to know more about it.

3. Inclusive education is necessary to understand but they may be reluctant to know more about it.

4. Teachers are not aware they will always encounter inclusion in their day-to-day teaching-learning processes.

5. Teachers may be waiting for knowledge sharing from the relating education agents.

Based upon the explanations and reviews above, the writer formulates the problems of the study as the following:

1. To what extent do Islamic Elementary School Teachers comprehend inclusive education?

2. To what extent are the perceptions of Islamic Elementary School Teachers towards inclusive education?

3. To what extent are the attitudes of Islamic Elementary School Teachers towards inclusive education?

\section{The Terms of Inclusion}

The definition of inclusion goes more beyond students with disabilities and views the innumerable ways that students differ from one another as the differences in race, class, gender, ethnicity, family background, sexual orientation, language, ability, size, religion, and the like (Mara Sapon-Shevin, 2007: 10). James McLeskey and Nancy L. L. Waldron (2000:50) compare between inclusion and non-inclusion as follows: 
Table 1

Compare Between Inclusion And Non-Inclusion

\begin{tabular}{|c|c|}
\hline Inclusion Means & Inclusion Does Not Mean \\
\hline $\begin{array}{l}\text { 1. Students with disabilities } \\
\text { attend their neighborhood } \\
\text { school or the school they } \\
\text { would attend if they were not } \\
\text { disabled. }\end{array}$ & $\begin{array}{l}\text { 1. "Dumping" students with } \\
\text { disabilities into general } \\
\text { education classrooms without } \\
\text { careful planning and adequate } \\
\text { support. }\end{array}$ \\
\hline $\begin{array}{l}d \text { is in an age- } \\
\text { te general education }\end{array}$ & $\begin{array}{l}\text { 2. Reducing services or funding } \\
\text { for special education services. }\end{array}$ \\
\hline $\begin{array}{l}\text { 3. Every student is accepted and } \\
\text { regarded as a full and valued } \\
\text { member of the class and } \\
\text { school community. }\end{array}$ & $\begin{array}{l}\text { with students who have } \\
\text { disabilities or who are at risk. } \\
\text { 4. Teachers spend a } \\
\text { disproportionate amount of }\end{array}$ \\
\hline $\begin{array}{l}\text { 4. Special education supports are } \\
\text { provided within the context of } \\
\text { the general education }\end{array}$ & $\begin{array}{l}\text { ing or adapting } \\
\text { a for students with }\end{array}$ \\
\hline & \\
\hline $\begin{array}{l}\text { ive an } \\
\text { ddresses their }\end{array}$ & $\begin{array}{l}\text { ically, } \\
\text { ne } \\
\text { oom. }\end{array}$ \\
\hline $\begin{array}{l}\text { tion of } \\
\text { abilities } \\
l \text { and }\end{array}$ & $\begin{array}{l}\text { ment } \\
\text { dents } \\
\text { on or } \\
\text { um. }\end{array}$ \\
\hline $\begin{array}{l}\text { S excluded on the } \\
\text { pe and degree of }\end{array}$ & $\begin{array}{l}\text { chers are } \\
\text { of } \\
\text { al }\end{array}$ \\
\hline $\begin{array}{l}\text { 8. The school promotes } \\
\text { cooperative/ collaborative } \\
\text { teaching arrangements. }\end{array}$ & $\begin{array}{l}\text { lassroom. } \\
\text { eral and special } \\
\text { eachers to team }\end{array}$ \\
\hline $\begin{array}{l}\text { 9. There is building-based } \\
\text { planning, problem solving, } \\
\text { and ownership of all studen } \\
\text { and programs. }\end{array}$ & $\begin{array}{l}\text { ithout careful } \\
\text { ind well-defined } \\
\text { lities. }\end{array}$ \\
\hline
\end{tabular}

\section{The Terms of Inclusive Education}

Armstrong at.al. (2010) note that:

1. The idea of 'inclusive education', actually goes well beyond special education in terms of its approach to social integration 
although historically it is closely related to debates and reforms in the field of special education;

2. This should be comprehended in terms of an approach to the 'problems' of social diversity as the result of social changes after the Second World War including the end of colonialism, the increase of labor-force mobility, and the tension between global and local cultures;

3. There are consequential contradictions between conceptions and practices because education systems attempt to manage the social and economic complexities of national and cultural identity in societies that are highly diversified internally but globally interconnected;

4. The increase of 'inclusive education', particularly in the developing countries indicates the efforts of the countries to promote access of social and educational advantages to schooling and educational resources, as well as reflecting the borrowing of the first-world thoughts to countries which reinforces dependency and what Paulo Friere calls 'the culture of silence'.

One of the debates, for instance, focuses on whether students with special needs should be integrated or separated with the common students. Some disagree that students with disability should be separated because they have the same rights with the regular students. But some support the separation because the former needs special attention and treatments. In addition, the terms of inclusion are also polarized because this is not only limited to the disabled students but broader as those who are disadvantageous as a result of poverty, sexuality, minority ethnic status, or other characteristics assigned significance by the dominant culture in their society (Ballard, 2005:2).

Villa (2005: 5) says that inclusive education means embracing everyone and making a commitment to provide every student with a community, every citizen with a democracy and the undeniable right to belong. Inclusion supports that living and learning together are advantageous everyone, not just children who are labeled as having a difference (e.g., those who are gifted, are non-English proficient, or have a disability). She concludes that inclusion is a belief system, not just a set of strategies. Separated education creates 
a permanent underclass of students and conveys a strong message to those students that they do not measure up, fit in, or belongs.

The inclusive education should not be segregated in school institutions since it is obvious that we can understand and appreciate differences only if we are surrounded by different people. Otherwise, our understanding, our acceptance, and even our tolerance are only academic paradigms. Within inclusive environments, students are not only showed by great varieties of people and their differences, but also learn how to talk about their differences, ask critical questions, and get along with the others (Mara Sapon-Shevin, 2007: 18).

On the contrary, Cor J.W.Meijer, Sip Jan Pijl and Seamus Hegarty, 2002:1) suggest that the separate system used to be seen as an expression of the care for pupils with special needs. They learn from the educational system in the Netherlands. In this country, the educational system is divided into two namely regular schools and special schools. Compared with many other European countries, the Dutch special education system is extensive, differentiated, and segregated.

In New Zealand, as elsewhere, the disabled students are those who were most obviously excluded from ordinary schools, classrooms and learning opportunities, and their integration was a project originated by their parents and extending across many years (Sonntag, cited by Ballard, 2005:1). In Europe, North America and Australia throughout the twentieth century, the disabled children are those who are categorized as having 'handicap' or 'impairment' and growth in the number of schools outside the mainstream for children whose needs were seen as different to those of 'normal' children. In these countries, however, the concept of special educational needs was never simply synonymous with 'impairment' (Armstrong, 2010:5).

Since special education is polarized, special education is conceived differently in different parts of the world and is practiced variously accordingly (Pijl,2002: xi). The terms of inclusive education in Indonesia is closely related to wider education context. Therefore, it is not limited to the disabled students but for those who are disadvantageous in terms of emotional, mental, intellectual, and 
social aspects, including students who live in a very remote areas. The rights and obligatory responsibilities of Indonesian citizens in terms of inclusive education are implicitly formulated in Chapter IV, article 5, verses 1,2,3,4, and 5, of Indonesian Republic Regulations Number 20 Year 2003 about National Education Systems (UndangUndang RI Nomor 20 Tahun 2003 Tentang Sistem Pendidikan Nasional). It is said that 1 ) the very citizen has the same right to get the qualified education, 2) citizens with disability physically, emotionally, mentally, and or socially have opportunities to get special education, 3) citizens who live in a very remote places or suburb areas and the very rural communities right to have very-special education, 4) citizens having intellectual potential and special capabilities have rights to get special education, and 5) the very citizen rights to have opportunity to improve the life-long education.

From the five verses mentioned above, inclusive education and for some extent 'special education' in Indonesian National Education System is comprehensive. The regulations cover not only students with disabilities physically but also those who are disadvantageous emotionally, mentally, and socially as because of poverty, retardation, and illiteracy. In addition, the national education systems also give attentions to students who live in remote areas or in the very rural communities, clever students and the students who have specific capabilities. All should be accomplished in life-long processes.

To accomplish such kinds of ideal education systems, there must be at least three processes namely transformation of the knowledge, comprehension of the transferred knowledge, and the implementation in the day-to-day practices. To implement the three prerequisites, there are two figures that are responsible to so doing i.e. education policy makers in the case are the stakeholders of the school institutions and the practitioners in this case are teachers. The two sides should go hand in hand to strengthen cooperation because inclusive education is a very big agenda. The policy makers are responsible to socialize about the policies and the regulations for the implementation. Then, the practitioners need to comprehend the knowledge and implement the knowledge in the education practices. 
The position of teachers is very central for the implementation of inclusive education because the teachers will be immediately to encounter students with disabilities in the school practices. They are considered as the most important persons who are responsible to the conduct of the inclusive education. They should be objective in that conduct because subjectivity is not itself inclusive but exclusive. To be inclusive teachers, they should know holistically what inclusive education is.

\section{The Concept and Implementation of Inclusive Education}

Some studies show that inclusive education is a sophisticated issue in terms of concepts as well as its implementations. Conceptually, there are two main paradigms of inclusive education namely integration and separation. The former supporters say that inclusive education should be integrated in regular school institutions, so there must not be inclusive schools. The second paradigm suggests that there must be separation between regular students and students with disabilities as the case in the Netherlands that divides education system into two namely regular schools and special schools (J.Pijl, Ysbrand, at.al.,2005:10).

Besides the polarization in conceptualization, the problem also appears in the implementations of inclusive education. Pijl and Meijer (2005) identify three factors that may influence the conduct of inclusive education i.e. teacher factors, school factors, and external factors. Because of the factors, it is possible that special education is conceived differently in different parts of the world and is practiced variously accordingly (Pijl,2002: xi).

The concept of inclusive education is extended to the wider context of 'social inclusion', addressed to those who are marginalized, unproductive and non-participative in society. This can be in family, friendships, and community, education, workplace and leisure activities. Shucksmith, 2000 cited by Topping at.al. (2005: 2) says that social exclusion is associated with complicated problems such as poor skills, unemployment, low incomes, poor housing, high crime environments, bad health and family breakdowns. This is not always identical with purely urban phenomena but may be shared to non-urban communities. 
A research conducted by Pavlovic Slavica (Department of Education Science, Faculty of Sciences and Education, University of Mostar, Mostar, Bosnia and Herzegovina) shows that 1) more than $80 \%$ of primary teachers in Herzegovina-Neretva Canton (HNC) are neither available nor educated enough for the implementation of the inclusive education in their schools, 2) almost a half of primary school teachers in HNC (49.52\%) strongly agree that schools are not ready for the inclusive education. Their opinion is also supported by more than a third of teachers (37.14\%), and 3) more than $90 \%$ of teachers say that they need additional education and training to be able to work with pupils with special needs.

The research result conducted by Ýsa Korkmaz from Selcuk University, Konya, Turkey entitled Elementary Teachers' Perceptions about Implementation of Inclusive Education shows various tendencies on the inclusive education. From 66 participants of the research 1) 34 participants say that inclusive education is okay if the size of the classroom is small, 2) 18 participants agree if disabilities students should be partly included in classrooms, (3) while 14 participants say that all kinds of disabilities should not be included in classroom activities.

The next study was conducted by Yoon-Suk Hwang (Queensland University of Technology) and David Evans (University of Sydney) entitled Attitudes towards Inclusion: Gaps between Belief and Practice, addressed to 33 Korean general education teachers from three primary schools in Seoul concerning their attitudes towards, and willingness to accommodate, the needs of students with disabilities. The results show that $41.37 \%$ of general education teachers had positive attitudes towards inclusion programs, while $55.16 \%$ were unwilling to actually participate.

This looks that even though some of the general education teachers in the Republic of Korea (41.37\%) agree to include students with disabilities in general education settings, but more than half (55.16\%) disagree to include the students in such settings.

Exactly, schools should think about numerous differences, since everyone has multiple identities including racial, ethnic, religious, familial, language, gender, and etcetera. Accordingly, 
inclusive schools require that teachers be responsible to all children and not simply to one aspect or characteristic (Mara Sapon-Shevin, 2007: 11).

Based on the studies, this is proven that teachers play important roles in terms of comprehension and perception of inclusive education and its implementation. Even, Sip Jan Pijl and Cor J.W.Meijer (2002) say that teacher is one of the three important factors for the successful implementation of inclusive education. The conduct of inclusive education very depends upon their attitude towards pupils with special needs and the resources available to it. Hegarty (1994) cited by Sip Jan Pijl and Cor J.W.Meijer (2002) reminds that in a number of studies the attitude of teachers towards educating pupils with special needs has been put forward as a decisive factor in making schools more inclusive (Hegarty 1994). They sum up that teacher' attitudes, available time allotment, the knowledge and skills of teachers, the teaching methods, and the materials seem to be important prerequisites for special needs.

Rose (2010: 1-2) says that understanding demands efforts. Even at the age of increased mass communication technology when it is relatively simple to share ideas and perspectives but it is not always easy to interpret the meaning of the messages we receive. James McLeskey and Nancy L. L. Waldron (2000: 48) say if teachers and administrators do not understand the need to examine and change some of their beliefs concerning inclusion and schooling, the result of inclusive program will likely entail only superficial change.

The concept and implementation of inclusive education do not yet spread in all areas - even in all universities in terms of Indonesia. Therefore, although inclusive education has started in 1980 's in western countries but it has not gotten proportional responses in this country. This is proven by an International Workshop entitled "Toward Inclusive Education for Universities in Indonesia" conducted by Brawijaya University in cooperation with the Directorate General of Higher Education, the Ministry of National Education from 10 - 11 November 2012. This was followed by participants from around 50 (fifty) state and private universities in Indonesia. One of the recommendations proposed from the workshop is the 
commitment to implement inclusive education for the disabled students in Indonesia. In addition, there must be a wide access for the disabled students to get a proportional education as the normal students (accessed in November, $15^{\text {th }} 2012$ at 10:15 AM: http:// www.dikti.go.id/?p=6958\&lang=id).

Since the concept of inclusive education has not yet spread all over, the implementation and the research concerning inclusive education are not also spread on the whole. There are various ways to comprehend and implement inclusive education from place to place, from area to area, and for some extent from university to university.

One of the research projects was conducted by Zaenal Alimin in 2011. He described the Implementation Profile of Inclusive Education in Bandung City. His samples were 10 classrooms from four Elementary Schools in the City. He was going to find out 1) the existence of students with special needs in Elementary Schools which conduct inclusive education; 2) the inclusion indexes achieved by Elementary Schools which conduct inclusive education; and 3) the ways of achieving inclusion indexes for the Elementary Schools which conduct inclusive education. His findings show that 1) there are about 1 up to 4 students, and averagely 2 students with special needs in a classroom with the total number minimally 20 students and maximally 46 students on the whole; 2) the average inclusion indexes are 38.58 with the ideal indexes 54; 3) the higher inclusion indexes are achieved by classrooms having more than one teacher, having greater students with special needs, having lesser total number of students with special needs, and having teachers who often join training in inclusive education (accessed in November $11^{\text {th }} 2012$ at 11.22 AM: http://repository.upi.edu/operator/upload/pros_uiuitm_2011_zaenal_profil_implementasi_pendidikan_inklusif.pdf)

Besides such a kind of research, there are still many; but the writer used the last point relating to the comprehension processes for the extended implementation of the inclusive education. For the conclusion, the more often the teachers join training in inclusive education, the better their understanding on the inclusion - and for some extent the ability for implementing the inclusive education. In 
addition, the samples used in this research are regular schools which do not conduct inclusive education.

Based upon the theories, explanations, and the implementation sample of inclusive education above, it is understandable that teachers are able to more comprehend inclusive education from many ways. Introduction from relating educational agents is the most expected way. In addition, they are able to comprehend the concept of inclusive education through seminar, training or workshop which is conducted by the agents including by university institutions. Since the conceptualization of inclusive education varies, the implementation may also vary. However, the primary message of inclusive education conduct must be equal namely giving the same opportunities to the disabled students to access the equal education processes as the regular students. Whatever the ways used, the better understanding on inclusive education the better the implementation of it.

\section{Research Methodology}

Based upon the research procedures which had been conducted later on, this study is included into quantitative research (Sugiyono, 2008:v). In terms of the natural setting, this is included in survey research (Sugiyono, 2008: 4). Survey research is used to find out facts from research setting naturally and the researcher uses treatments for collecting the research data. The treatments can be in the form of questionnaires, tests, structural interviews, and the like (Sugiyono, 2008: 6).

The research participants of this study were all Islamic Elementary School Teachers in Salatiga town. Based upon the preliminary information from the Ministry of Religious Affairs of Salatiga (2008), there are twelve Islamic Elementary Schools in Salatiga. One is state school, and the others are private institutions that are conducted by diversified social-mass organizations. In the schools, there are one hundred and twenty two teachers. Eight teachers work in State Islamic Elementary Schools and one hundred and fourteen work in Private Islamic Elementary Schools. 
The samples of this research were seventeen teachers from one hundred and twenty two persons or $14 \%$ from the participants. The technique used to get the sample of the research was probability simple random sampling. The writer used questionnaire as the primary data collection method and structural interviews as the secondary data collection method.

The data collected will be analyzed by using Interactive Model developed by A. Michael Huberman and Matthew B. Miles consisting of data reduction, data display, and conclusion drawing/verification (Miles \& Huberman, 1984, 1994: 428-429). The components of data analysis: interactive model can be seen in the following figure:

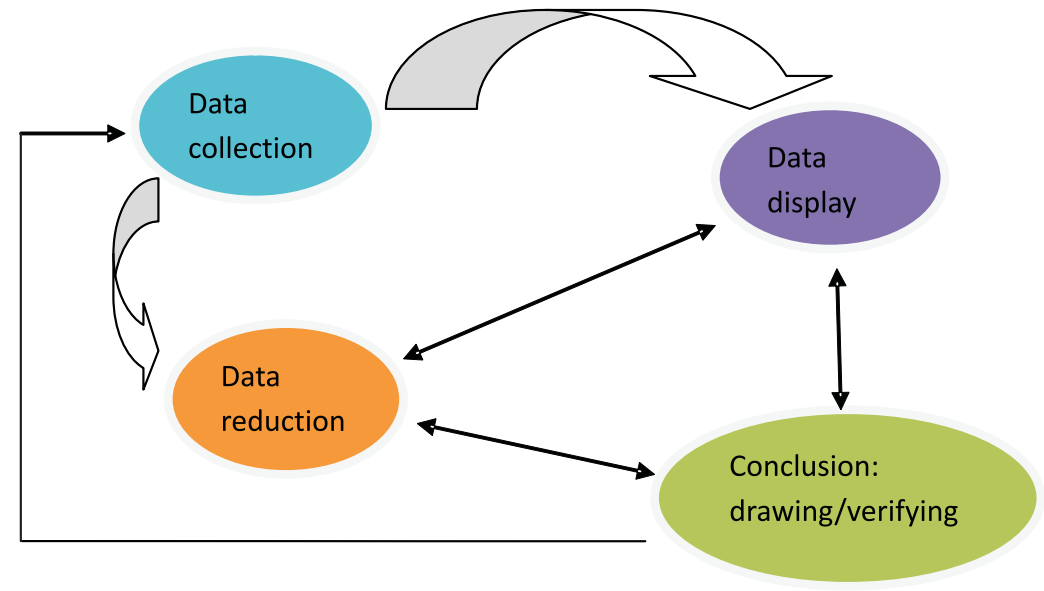

Figure 1: Components of Data Analysis: Interactive Model

\section{Analysis}

The writer divides the writing into several sub chapters namely data collection, data display, data reduction, data analysis and discussion.

These research data were primarily collected through questionnaire. There are two types of questionnaires namely completion and option. The former was used to find out general information concerning gender, age, education level, and teaching experiences. The latter was used to find out specific information concerning teachers' comprehensions, perceptions, and attitudes towards inclusive education. Also, the secondary data collection method, namely interview was 
used to complete the former. From the seventeen participants, only fourteen who returned the questionnaires. The result of the questionnaires are presented as follows:

1. Teachers' comprehensions to inclusive education

Table 1.

Teachers' Comprehensions on Inclusive Education

\begin{tabular}{|c|c|c|c|c|c|c|}
\hline \multirow[b]{2}{*}{ No. } & \multirow[b]{2}{*}{ Questions } & \multicolumn{5}{|c|}{ The Percentage of Answer } \\
\hline & & $\begin{array}{l}\text { Strongly } \\
\text { disagree }\end{array}$ & Disagree & Neutral & $\begin{array}{c}\text { Strongly } \\
\text { agree }\end{array}$ & Agree \\
\hline 1. & $\begin{array}{l}\text { I feel that my } \\
\text { comprehension } \\
\text { concerning } \\
\text { inclusive education } \\
\text { is relatively } \\
\text { sufficient }\end{array}$ & $7.1 \%$ & $71.4 \%$ & $14.4 \%$ & - & $7.1 \%$ \\
\hline 2. & $\begin{array}{l}\text { I feel that I need } \\
\text { not to improve my } \\
\text { understanding } \\
\text { about inclusive } \\
\text { education }\end{array}$ & $42.9 \%$ & $50 \%$ & - & - & $7.1 \%$ \\
\hline 3. & $\begin{array}{l}\text { I feel that I have } \\
\text { gotten sufficient } \\
\text { inclusive education }\end{array}$ & $14.4 \%$ & $78.5 \%$ & $7.1 \%$ & - & - \\
\hline \multicolumn{2}{|c|}{ Total } & \multicolumn{2}{|c|}{$88.1 \%$} & $7.1 \%$ & \multicolumn{2}{|c|}{$4.7 \%$} \\
\hline
\end{tabular}

Based upon table 1 above, it seems that most of teachers in Islamic Elementary Schools have not yet had sufficient comprehensions concerning inclusive education. Only $7.1 \%$ who has sufficiently, and $14.4 \%$ who have neutrally comprehensions to inclusive education; while $78.5 \%$ have insufficient comprehensions to the education. There may be caused by the ongoing and the post going education processes. In the ongoing processes, almost of the teachers (92.9\%) have insufficient inclusive education; and $7.1 \%$ does not believe that he/she got inclusive education (neutral). In the post education processes, they almost never join - whether in seminar or workshop, on inclusive education. Therefore, most of them (92.9\%) need improvement concerning inclusive education, and only $7.1 \%$ who does not believe concerning the improvement. In a little interview, most of the teachers much need contribution from the Ministry of Religious and Education Affairs as well as Universities to improve their comprehensions on inclusive education. The improvement may be through intensive socialization, seminar 
or workshop. By the ways, they expect to be able to identify and manage classroom with students having special needs.

2. Teachers' perceptions to inclusive education

Table 2.

Teachers' Perceptions to Inclusive Education

\begin{tabular}{|c|c|c|c|c|c|c|}
\hline \multirow[b]{2}{*}{ No. } & \multirow[b]{2}{*}{ Questions } & \multicolumn{5}{|c|}{ The Percentage of Answer } \\
\hline & & $\begin{array}{l}\text { Strongly } \\
\text { disagree }\end{array}$ & Disagree & Neutral & $\begin{array}{c}\text { Strongly } \\
\text { agree }\end{array}$ & Agree \\
\hline 1. & $\begin{array}{l}\text { I feel that } \\
\text { education facilities } \\
\text { provided have } \\
\text { accommodated the } \\
\text { needs of students } \\
\text { with special needs }\end{array}$ & $21.4 \%$ & $42.9 \%$ & $28.7 \%$ & - & $7.1 \%$ \\
\hline 2. & $\begin{array}{l}\text { I feel that school } \\
\text { institutions get } \\
\text { difficulties to } \\
\text { provide education } \\
\text { facilities for } \\
\text { students with } \\
\text { special needs }\end{array}$ & - & $42.9 \%$ & $42.9 \%$ & $7.1 \%$ & $14.4 \%$ \\
\hline 3. & $\begin{array}{l}\text { I feel that the } \\
\text { given curricula } \\
\text { have } \\
\text { accommodated the } \\
\text { needs of students } \\
\text { with special needs }\end{array}$ & $7.1 \%$ & $50 \%$ & $21.4 \%$ & - & $21.4 \%$ \\
\hline 4. & $\begin{array}{l}\text { I feel that I get } \\
\text { ready to arrange } \\
\text { inclusive classroom }\end{array}$ & $7.1 \%$ & $28.7 \%$ & $28.7 \%$ & $7.1 \%$ & $28.7 \%$ \\
\hline 5. & $\begin{array}{l}\text { I feel that I get } \\
\text { ready to manage } \\
\text { inclusive classroom }\end{array}$ & - & $50 \%$ & $28.7 \%$ & $7.1 \%$ & $14.4 \%$ \\
\hline \multicolumn{2}{|c|}{ Total } & \multicolumn{2}{|c|}{$50.02 \%$} & 30.08 & \multicolumn{2}{|c|}{21.46} \\
\hline
\end{tabular}

As the previous explanations about teachers' comprehensions concerning inclusive education, teachers' perceptions to the education are also needed to be observed conscientiously. In table 2 it is seen $21.4 \%$ strongly disagree and $42.9 \%$ disagree that education facilities provided have accommodated the needs of students with special needs; and $28.7 \%$ are neutral and only $7.1 \%$ agrees with the given facilities. This means that almost $64.3 \%$ say that education facilities are insufficient for fulfilling the needs of students with special needs. However, they disbelieve that school institutions are not able to provide such facilities. They may have to 
do or be able to do; so $42.9 \%$ disagree with the difficulties, $42.9 \%$ are neutral, and $7.1 \%$ strongly agrees and $14.4 \%$ agree with the school institutions to provide facilities needed by students with special needs. In addition to education facilities, the curricula are not yet prepared for students with special needs. There are $7.1 \%$ who strongly disagrees and $50 \%$ who disagree that the curricula have accommodated the needs of disable students. Only $21.4 \%$ who are neutral and $21.4 \%$ who agree that the given curricula are appropriate for disable students. Because of such facts, the readiness of the ready teachers and unready teachers are fifty - fifty. About $7.1 \%$ strongly disagrees and $28.7 \%$ disagree with their readiness to prepare inclusive education as the same as those who strongly agrees (7.12 $\%)$ and agree (28.7\%) with such a preparation. The rest of the participants (28.7) is neutral concerning the preparation. Since they are not absolutely ready to prepare inclusive classroom, they also do not get ready (50\%) to manage inclusive classroom, $28.7 \%$ are neutral, and only $21.5 \%$ who get ready to manage the inclusive classroom. They perceptions on inclusive classroom are understandable because they have insufficient comprehensions on the inclusion.

3. Teachers' attitudes on inclusive education

Table 3.

Teachers' Attitudes towards Inclusive Education

\begin{tabular}{|c|c|c|c|c|c|c|}
\hline \multirow[b]{2}{*}{ No. } & \multirow[b]{2}{*}{ Questions } & \multicolumn{5}{|c|}{ The Percentage of Answer } \\
\hline & & $\begin{array}{l}\text { Strongly } \\
\text { disagree }\end{array}$ & Disagree & Neutral & $\begin{array}{c}\text { Strongly } \\
\text { agree }\end{array}$ & Agree \\
\hline 1. & $\begin{array}{l}\text { I feel that students } \\
\text { with special needs } \\
\text { should study } \\
\text { together with } \\
\text { regular students }\end{array}$ & $7.1 \%$ & $35.7 \%$ & $28.7 \%$ & $7.1 \%$ & $21.4 \%$ \\
\hline 2. & $\begin{array}{l}\text { I feel that inclusive } \\
\text { classroom should } \\
\text { not be separated } \\
\text { with regular } \\
\text { classroom }\end{array}$ & $21.4 \%$ & $21.4 \%$ & $7.1 \%$ & - & $50 \%$ \\
\hline 3. & $\begin{array}{l}\text { I feel that students } \\
\text { with special needs } \\
\text { are able to follow } \\
\text { teaching-learning } \\
\text { processes as the } \\
\text { regular students }\end{array}$ & $14.4 \%$ & $28.7 \%$ & $7.1 \%$ & $7.1 \%$ & $42.9 \%$ \\
\hline
\end{tabular}




\begin{tabular}{|c|c|c|c|c|c|c|}
\hline 4. & $\begin{array}{l}\text { I feel that students } \\
\text { with special needs } \\
\text { will have more } \\
\text { self-esteem if they } \\
\text { study together with } \\
\text { regular students }\end{array}$ & $14.4 \%$ & $28.7 \%$ & - & $14.4 \%$ & $42.9 \%$ \\
\hline 5. & $\begin{array}{l}\text { I feel that students } \\
\text { with special needs } \\
\text { are able to } \\
\text { cooperate with the } \\
\text { regular students }\end{array}$ & $7.1 \%$ & $7.1 \%$ & $21.4 \%$ & $7.1 \%$ & $57.1 \%$ \\
\hline 6. & $\begin{array}{l}\text { I feel that teaching- } \\
\text { learning } \\
\text { processes will be } \\
\text { disturbed when } \\
\text { students with } \\
\text { special needs study } \\
\text { together with the } \\
\text { regular students }\end{array}$ & - & $14.4 \%$ & $42.9 \%$ & 7.1 & $35.7 \%$ \\
\hline 7. & $\begin{array}{l}\text { I feel that students } \\
\text { with special needs } \\
\text { have relatively the } \\
\text { same academic } \\
\text { capabilities as the } \\
\text { regular students }\end{array}$ & $21.4 \%$ & $42.9 \%$ & $21.4 \%$ & - & $14.4 \%$ \\
\hline Total & & \multicolumn{2}{|c|}{37.81} & 18.37 & \multicolumn{2}{|c|}{$43.89 \%$} \\
\hline
\end{tabular}

Teachers' attitudes towards inclusive education relatively stay in between. They do not absolutely disagree or agree with inclusion. The first concerns with the ideas whether or not disable students and regular students should be mixed at the same classroom. 7.1\% and $35.7 \%$ participants strongly disagree and disagree if disable students study together with regular students. Some of them (28.7 \%) are neutral or stay in between, while $28.5 \%$ agree if they are mixed in a classroom ( $7.1 \%$ strongly agree and $21.4 \%$ just agree). The previous ideas concerning the blend between such kinds of students in disagreement pole and agreement pole portrait the second tendency dealing with the separation. If in the former about $42.8 \%$ who disagree with the blend, the same percentage also appears (42.8\%) who agree with the separation. Thus, some of them (50\%) disagree with the separation and only $7.1 \%$ who is neutral. This means that the supporters for blending is greater than that of the separation. The third tendency also depicts the first and the second ones, since $43.1 \%$ of the participants disbelieve that disable students are able to follow teaching-learning processes as the regular students. However, $50 \%$ of them still believe on their 
capability to follow the class as the regular students and only $7.1 \%$ who are neutral on their capability. The same trend could also be seen in the following answer by which $43.1 \%$ participants feel that disable students will not have more self-esteem even though they study together with the regular students. By contrast, $57.3 \%$ of the participants believe that the blend will increase disable students' self-esteem. Based upon the facts above, $14.2 \%$ participants do not believe that disable students are able to cooperate with regular students, $21.4 \%$ participants are neutral, and 64.2\% (7.1\% strongly agree and $57.3 \%$ agree) participants believe that disable students are able to cooperate with the regular students. The last two answer concerning whether or not teaching-learning processes are disturbed when disable students study together with regular students also portraits the previously mentioned tendencies. Around $42.8 \%$ participants believe that the class will be broken if the disable students are fused in a class, $42.9 \%$ are neutral and only 14.4 who agree that teaching-learning processes will not be disturbed when students with special needs study together with the regular students. The last point is the assumption that disable students have relatively the same academic capabilities as the regular students. At the last point, $64.3 \%$ participants do not believe that disable students have relatively the same academic capabilities as the regular students, $21.4 \%$ are neutral, and $14.4 \%$ participants do agree that students with special needs have relatively the same academic capabilities as the regular students.

To be clear, the writer presents the total account of the calculation, namely the calculation of teachers' comprehensions, perceptions, and attitudes towards inclusive education. The result of this research shows that the teachers' comprehensions to inclusive education (as in table 1 above) are still very low. $88.1 \%$ participants feel that their comprehensions and education on inclusive education need to be improved. In interviews, they expect that such educational agents as the Ministry of Religious and Education Affairs as well as University Institutions involve them for the improvement. So far, there is no intensive socialization, seminar, or workshop from the agents. In the future, it is expected that those agents contribute a lot in such improvement programs. Borrowing Rose's ideas (2010: 1-2) 
it is not always easy to access information in increased mass communication technology.

Whatever, it is necessary to reconsider the importance of reading as recommended in the holy Qur'an. The first revelation (surah al A'la: 1 - 5) given to the Prophet Muhammad SAW is as if reminding us all Muslims to intensify our daily activity to read. Reading should not only be a routine but necessity because reading is the window of the world. Moreover, reading is much recommended in Islamic Institutions which are so far considered as secondary educational institutions. The negative stamp will change if Muslims voluntarily change this. Unless, there will be no changing ( Surah Ar-Ra'd:1).

Since the comprehensions of teachers are low, it is undeniable that their perceptions to inclusive education are negative; because comprehension to something will consider the perception of the thing. In table two it is seen that $50.02 \%$ of the participants disbelieve with the available facilities and the readiness to provide the facilities, curricula, and their readiness to prepare and manage the inclusive classroom. Only $21.46 \%$ participants have positive expectations to the preparing practice of inclusion.

The last section of this research portrait the teachers' attitudes towards inclusive education. Based upon the result of table 3 , it is still fortunate because even though the teachers' comprehensions are very low, and their perceptions are also negative; but their attitudes towards inclusive education are still better. It is said that $(43.89 \%)$ have positive attitudes greater than those $(37.81 \%)$ that have negative attitudes to inclusion.

In terms of Islamic Institutions and for some extent Islamic teachings, the findings of this research should be thought carefully because Islam is 'rahmatan lil 'alamiin' (Al Anbiyaa: 21). To so doing, it better if all Islamic institutions try very hard to achieve this ambition. As said before, The Al Mighty God 'Allah s.w.t.' will never change the Muslims fate unless they try hard to change themselves, including changing the quality of education. In addition, they should work hand in hand, cooperate together to make the hard work become easier (Al Maidah: 2). 
Since Islam was sent to be 'rahmatan lil 'alamiin' Muslims should have positive attitudes to students, including to the students with special needs. They should be aware that there must be inclusive students in every class. As explained at the previous chapters, inclusion is beyond special education. Therefore, teachers may find out students with special intelligences; students who are very passive, aggressive, attention problems, perfectionist, and socially inept, and the like in their classrooms, who need special needs. They have the same rights to get education.

\section{Conclusion}

Based upon data analyses and discussions above, the writer is able to draw conclusion as follows:

1. Most of Islamic Elementary School Teachers consider that inclusive education is a relatively new phenomenon in their mind and practice. The result of the survey shows that teachers $(88.1 \%)$ have fewer comprehensions concerning inclusive education; and are only $4.7 \%$ who feel having a little knowledge about it. They have so comprehensions because they did not get sufficient knowledge when they were still studying in universities. In addition, they are also not experienced well in intensive seminar or workshop dealing with inclusive education conducted by related institutions as the Ministry of Religious or Education Affairs and University Institutions.

2. Most of Islamic Elementary School Teachers (50.02 \%) have negative perceptions concerning inclusive education; and are only $21.46 \%$ who have positive perceptions of it. They have negative perceptions dealing with the availability of education facilities needed by disable students, even though school institutions may be able to provide such facilities. In addition, the curricula also do not yet accommodate the needs of the students. Therefore, most of them are pessimistic to prepare the inclusive education as well as to manage inclusive classroom.

3. Even though most of Islamic Elementary School Teachers have fewer comprehensions and negative perceptions to inclusive education, but they still have positive attitudes (43.89\%) to the 
inclusive education; and the others (37.81\%) have negative attitudes towards inclusion. Their expectation to the successful practice of inclusive education is greater than their assumption of the failure if among related institutions such as policy makers, university institutions and school institutions are able to cooperate together in socialization, seminar, and workshop concerning inclusion.

\section{References}

Armstrong, Ann Cheryl., Armstrong, Derrick, \& Spandagou, Ilektra. (2010). Inclusive Education International Policy \& Practice. London: Sage Publication Ltd.

Ballard, Keith. (2005). Inclusive Education: International Voices on Disability and Justice. London, UK: Falmer Press.

Denzin, Norman K. and Lincoln, Yvonna S. (1994). Handbook of Qualitative Research. London: Sage Publications.

Departemen Agama. (1974). Al Quraan and Terjemahannya. Jakarta: PT Intermasa.

Hwang, Yoon-Suk and Evans, David. (2011). Attitudes towards Inclusion: Gaps between Belief and Practice. International Journal of Special Education, Vol 26 No1 2011, Page: 140.

Korkmaz, Ýsa. (2011). Elementary Teachers' Perceptions About Implementation of Inclusive Education. US-China Education Review Vol. 8, No. 2, February 2011, Page 182.

Marzano, Robert J. (2003). Classroom management that works: research-based strategies for every teacher. Alexandria, USA: Association for Supervision and Curriculum Development (ASCD).

McLeskey, James, and L. Waldron, Nancy. (2000). Inclusive schools in action: making differences ordinary. Alexandria, USA: Association for Supervision and Curriculum Development (ASCD).

Pijl, Sip Jan., Meijer, Cor J.W., and Hegarty, Seamus (Editors). (2002). Inclusive Education: A Global Agenda. New York: Routledge.

Rose, Richard (Editor). 2010. Confronting Obstacles to Inclusion: International Responses to Developing Inclusive Education. 
New York: Routledge.

Sapon-Shevin, Mara. (2007). Widening the Circle: The Power of Inclusive Classrooms. Boston, Massachusetts: Beacon Press books.

Slavica, Pavlovic. (2010). Inclusive Education: Proclamations or Reality (Primary School Teachers' View). US-China Education Review Volume 7, No.10 (Serial No.71), October 2010, Page: 64-65.

Seputar Indonesia. (2012). Kelas Inklusi SD Dikembangkan. Selasa 7 April 2012.

Sugiyono. (2008). Metode Penelitian Kuantitatif, Kualitatif dan $R$ $\varepsilon D$. Bandung: Alfabeta.

Topping, Keith and Maloney, Sheelagh (Editors). (2005). The RoutledgeFalmer Reader in Inclusive Education. New York: RoutledgeFalmer.

Villa, Richard A. and Thousand, Jacqueline S. (Editors). (2005). Creating an Inclusive School-2nd ed. Alexandria, USA: Association for Supervision and Curriculum Development (ASCD). . (2008). Profil Kota Salatiga Tahun 2008. Salatiga: Bapeda. . (2006). Undang-Undang dan Peraturan Pemerintab RI tentang Pendidikan. Jakarta: Direktorat Jenderal Pendidikan Islam Departemen Agama RI.

http://www.dikti.go.id/?p=6958\&lang=id

http:// repository.upi.edu/operator/upload/ pros_uiuitm_2011_zaenal_profil_implementasi_pendidikan_inklusif.pdf 